DOI: https://doi.org/10.18371/fp.3(39).2020.215216

УДК 336.226 .322

\title{
АДМІНІСТРУВАННЯ ПОДАТКУ НА ДОДАНУ ВАРТІСТЬ В УКРАЇНІ: ПРОБЛЕМИ ТА ПЕРСПЕКТИВИ РОЗВИТКУ
}

\author{
ОНІЩЕНКО Ганна Василівна \\ аспірантка кафедри фінансів, банківської справи та страхування \\ Університету банківської справи \\ e-mail:krobinec8@ukr.net
}

\begin{abstract}
Анотація $B$ статті узагальнено теоретичні засади щзодо визначення сутності понять адміністрування податків та податку на додану вартість. Спираючись на аналіз нормативно-правової бази, розглянуто механізм електронного адміністрування податку на додану вартість, виявлено основні проблеми. Проаналізовано порядок реєстраиії податкової накладної/розрахунку коригування у Сдиному реєстрі податкових накладних та останні зміни щэодо штрафних санкиій за його порушення.

Ключові слова: адміністрування податків, податок на додану вартість, електронне адміністрування ПДВ, податковий кредит, податкове зобов'язання, відшкодування ПДВ.
\end{abstract}

Постановка проблеми. Побудова ефективної податкової системи передбачає зважену податкову політику та результативність адміністрування податків. Динаміка сучасних змін і викликів, пов'язаних 3 поглибленням глобалізаційних і інтеграційних процесів, формуванням інформаційного суспільства і побудовою цифрової економіки, вказують на необхідність набуття податковою системою адаптивних властивостей і готовності до трансформаційних змін задля забезпечення держави стабільними, надійними і необхідними податковими надхо-
Аннотация. B cmaтье обобщены теоретические основы по определению сущности понятий администрирования налогов и налога на добавленную стоимость. Опираясь на анализ нормативно-правовой базы, рассмотрены механизм электронного администрирования налога на добавленную стоимость, выявлены основные проблемы. Проанализирован порядок регистрачии налоговой накладной / расчета корректировки в Едином реестре налоговых накладных и последние изменения относительно итрафных санкичий за его нарушение.

Ключевые слова: администрирование налогов, налог на добавленную стоимость, электронное администрирование НДС, налоговый кредит, налоговое обязательство, возмещения НДС.

дженнями. При цьому, поряд 3 іншими завданнями, для податкового адміністрування пріоритетним стає оптимізація бюджетних надходжень без збільшення податкового навантаження. Це зумовлено тим, що, з одного боку, збільшення податкового навантаження вже неможливо, адже це негативно впливає на рівень інвестиційної і ділової активності, стимулює розвиток тіньової економіки, а 3 іншого - невирішеним залишається питання недотримання бюджетом податкових надходжень. Розв'язання цієї проблеми є можливим за рахунок упровадження 
сучасних методів і технологій, що дозволяють покращити якість роботи фіскальної служби, впроваджувати електронні сервіси, будувати в новому форматі відносини з платниками податків, розширити базу оподаткування, підвищити інформаційну відкритість, прозорість і результативність податкового адміністрування, оперативно, об'єктивно і справедливо вирішувати податкові спори, попереджувати не доброчесну поведінку та протидіяти ухиленню від сплати податків тощо. Означене безпосередньо стосується податку на додану вартість (ПДВ), де всі заходи реформування стосуються впровадження ефективних методів його адміністрування.

Аналіз останніх досліджень і публікацій. Дослідженню теоретикометодологічних засад i проблемних аспектів щодо сутності і значенню податку на додану вартість, його бюджетотворчої функції, механізмів і методичних підходів нарахування, сплати та відшкодування цього податку, ефективності ставок і пільгового оподаткування, фіскального контролю та подолання корупційних схем приділяється значна увага в наукових працях зарубіжних і вітчизняних науковців, а саме В. Андрущенко, Є. Аткінсона, Є. Балацького, Д. Бодена, П. Боровик, О. Василика, Н. Вовна, М. Дем'яненко, Т. Єфименко, І. Єфре-мової, В. Кальчевського, Д. Ковалевич, О. Комарової, М. Косова, А. Крисоватого, П. Кулика, І. Луніної, С. Мочерного, В. Д. Нордхауса, О. Оксенюка, В. Пасенко, О. Піхоцької, О. Покатаєвої, $\quad$ Р. Пославської, П. А. Самуельсона, М. Троянської та інших. Високо цінуючи науковий доробок учених, відмітимо, що підходи реформування порядку адміністру- вання податку на додану вартість потребують подальших системних і комплексних досліджень.

Метою статті $\epsilon$ узагальнення теоретичних засад i визначення сутності понять адміністрування податків і податку на додану вартість, проведення аналізу нормативно-правової бази та обсягів податку на додану вартість в структурі податкових надходжень i податкової ефективності з ПДВ, виявлення проблем податку на додану вартість та обгрунтування можливостей їх вирішення за рахунок удосконалення електронного адміністрування.

Виклад основного матеріалу. В означеній проблематиці дослідження важливим $є$ чітке визначення понятійного базису, до якого віднесемо тлумачення сутності таких понять як «адміністрування податків» і «податок на додану вартість».

Адміністрування податків $є$ достатньо широким поняттям, що зумовлюється різноманітністю позицій щодо його визначення.

Так, О.З. Дадашев і А.В. Лобанов вважають, що податкове адміністрування - це «організаційноуправлінська система реалізації податкових відносин, яка включає в себе комплекс методів і форм забезпечення податкових надходження до бюджету». Його основною метою, на думку вчених, є забезпечення встановлених податкових надходжень до бюджетної системи в оптимальному поєднанні методів податкового регулювання i податкового контролю [1].

Н.C. Шалімова та О.А. Магопец сутність податкового адміністрування обгрунтовують як «сукупність методів, прийомів і засобів інформаційного забезпечення, за допомогою яких органи державної виконавчої 
влади (в тому числі податкові адміністрації та інспекції всіх рівнів) надають функціонуванню податкового механізму заданий законом напрям i координують податкові дії при суттєвих змінах в економіці та політиці» [2, с.362].

B.I. Чиж, наголошуючи на важливості адміністрування податків, підкреслює його характеристичні особливості щодо суб'єктних взаємовідносин представників податкових служб і платників податків, процесу податкового управління, а також інформаційного, планово-аналітичного i контрольного забезпечення [3, с.48].
Можемо бачити, що єдність позицій дослідників полягає у дотриманні ними системного (В. Федосов [4, с. 342], А. Крисоватий [5, с.219], П. Бечко [6, c.126], I. Перонко, В. Красницький [7, c.22] та ін.) або управлінського (В. Андрущенко [8, с.35], В. Мельник [9, с.41], А. Нікітшин [10, с.39], А. Воронов [11] та ін.) підходів.

Компаративний аналіз підходів щодо визначення економічної сутності поняття «податок на додану вартість» надано в табл. 1.

Визначення сутності поняття «податок на додану вартість»

\begin{tabular}{|c|c|}
\hline Автор & Податок на додану вартість - це \\
\hline $\begin{array}{l}\text { О. Подолянчук } \\
{[12]}\end{array}$ & $\begin{array}{l}\text { непрямий загальнодержавний податок, який є складовою ціни то- } \\
\text { варів і послуг та включає податкові зобов’язання щодо постачання } \\
\text { товарів (послуг), податковий кредит щодо постачання товарів (по- } \\
\text { слуг) та зобов'язання перед бюджетом з ПДВ }\end{array}$ \\
\hline $\begin{array}{l}\text { М. Бондаря, } \\
\text { Н. Лисенка } \\
{[13, \text { с. } 218]}\end{array}$ & $\begin{array}{l}\text { загальнодержавний непрямий податок на споживну вартість, що } \\
\text { справляється } 3 \text { юридичних та фізичних осіб і є основним джерелом } \\
\text { наповнення Державного бюджету України }\end{array}$ \\
\hline С. Мочерний [14] & $\begin{array}{l}\text { непрямий податок, що встановлюється як надбавка до ціни то- } \\
\text { варів і послуг; сплачується підприємствами з суми приросту вартості } \\
\text { на даному підприємстві, обчисленої як різниця між виторгом від ре- } \\
\text { алізації товарів і послуг та сумою затрат на сировину, матеріали, } \\
\text { напівфабрикати, одержані від інших виробників }\end{array}$ \\
\hline $\begin{array}{l}\text { О. Оксенюк } \\
{[15, \text { с.17] }}\end{array}$ & $\begin{array}{l}\text { податок на споживання, який стягується із доданої вартості, що } \\
\text { створюється на кожному етапі виробництва, сплачується кінцевим } \\
\text { споживачем та вноситься до бюджету продавцем, за винятком } \\
\text { випадків здійснення операцій за участі нерезидентів }\end{array}$ \\
\hline $\begin{array}{l}\text { Т. Дугар } \\
{[16, \text { с. } 690]}\end{array}$ & $\begin{array}{l}\text { непрямий податок з доданої вартості, яка створюється на всіх } \\
\text { стадіях виробництва й обігу, що включається у вигляді надбавки в } \\
\text { ціну товару, робіт та послуг і цілком оплачується кінцевим спожива- } \\
\text { чем товарів, робіт, послуг }\end{array}$ \\
\hline $\begin{array}{l}\text { А. Ходикіна } \\
{[17, \text { с. } 1197]}\end{array}$ & $\begin{array}{l}\text { непрямий податок, який стягується до бюджету у вигляді надбав- } \\
\text { ки до ціни продукції (робіт або послуг) і сплачується споживачами. }\end{array}$ \\
\hline
\end{tabular}

Джерело: сформовано автором на підставі опрацювання означених наукових праць

У структурі податкових надходжень, що формують доходи державного бюджету України, податок на додану вартість (ПДВ) та його адміністрування мають важливе значення. Серед надходжень загальнодержавних податків до бюджету частка ПДВ є найбільшою завдяки широ- 
кої сфери охоплення. Зокрема, за підсумками I кварталу 2020 року до Державного бюджету України надійшло 65,3 млрд грн ПДВ, що складає 69\% від загального обсягу надходжень в сумі 110,8 млрд грн.

Податкова ефективність 3 ПДВ у червні 2020 р. зросла до 3,5\% проти 2,5 \% аналогічного періоду 2019 р. За I півріччя платникам податків відшкодовано 75,1 млрд грн ПДВ, забезпечено скорочення заборгованості, що виникла у 2019 році. Залишок заявлених до відшкодування сум ПДВ станом на 01.07.2020 р. скорочено на $45 \%$, а саме до 15 млрд грн проти 27,4 млрд грн на 01.01 .2020 p. i 17,8 млрд грн на 01.07.2019 p. [29].

В Україні $з$ переходом до інформаційного суспільства почав діяти Закон України «Про податок на додану вартість» від 3 квітня 1997 р., що прийшов на заміну застарілим практикам Декрету Кабінету Міністрів України «Про податок на додану вартість». Закон України «Про податок на додану вартість» регулював порядок нарахування та сплати ПДВ до 1 січня 2011 року. На сьогодні справляння податку на додану вартість регулюється $\mathrm{V}$ розділом Податковий кодекс України (ПКУ) [18]. Відмітимо, що обрання Україною зовнішньополітичним пріоритетом європейську інтеграцію зумовило приведення нормативно-правових актів у відповідність до законодавства $\mathrm{CC}$, у тому числі в частині адміністрування податків, зокрема ПДВ. Новим кроком удосконалення нормативного регулювання стало прийняття Законів України № 1621 і № 1690 [19, 20], які, починаючи з січня 2015 року, визначають чіткі правила роботи системи електронного адміністрування ПДВ.
Станом на 01.01.2020 року в органах ДПС України перебувають на обліку 211 тис платників ПДВ, які пройшли обов'язкову або добровільну реєстрацію в системі електронного адміністрування.

Податок на додану вартість досить нейтральний до процесів ціноутворення, оскільки податковий тягар розподіляється рівномірно між усіма групами товарів і послуг, податок не впливає на поведінку платників, як учасників господарської діяльності, не примушує їх змінювати економічні piшення [21]. Широка база оподаткування, яка включає товари, роботи, послуги, забезпечує значні бюджетні надходження, а універсальні ставки полегшують обчислення ПДВ для платників. Проте складність електронного адміністрування ПДВ, зокрема в частині реєстрації податкових накладних / розрахунків коригування (ПН/РК), має, поряд 3 перевагами, певні недоліки. Серед таких варто відмітити: 1) складність механізмів нарахування і сплати податку; 2) високу вирогідність ухилення від сплати податку внаслідок недосконалості системи податкового обліку; 3) недостатній рівень прозорості надходжень до бюджету i, як слідство, виникнення бюджетної заборгованості; 4) тривалу в часі адаптацію до нововведень платників податків; 5) розмиванням податкової бази та виведенням прибутку 3під оподаткування тощо (рис. 1).

Водночас, визнаючи позитивні зміни, варто відмітити проблеми також в частині бюджетного відшкодування ПДВ щодо здійснення податкових перевірок, відмови або безпідставне анулювання ПДВ-реєстрації, тиску 3 боку правоохоронних органів у межах кримінальних проваджень, не обгрун- 
тованої відмови від відшкодування

ПДВ з боку фіскальних органів [28].

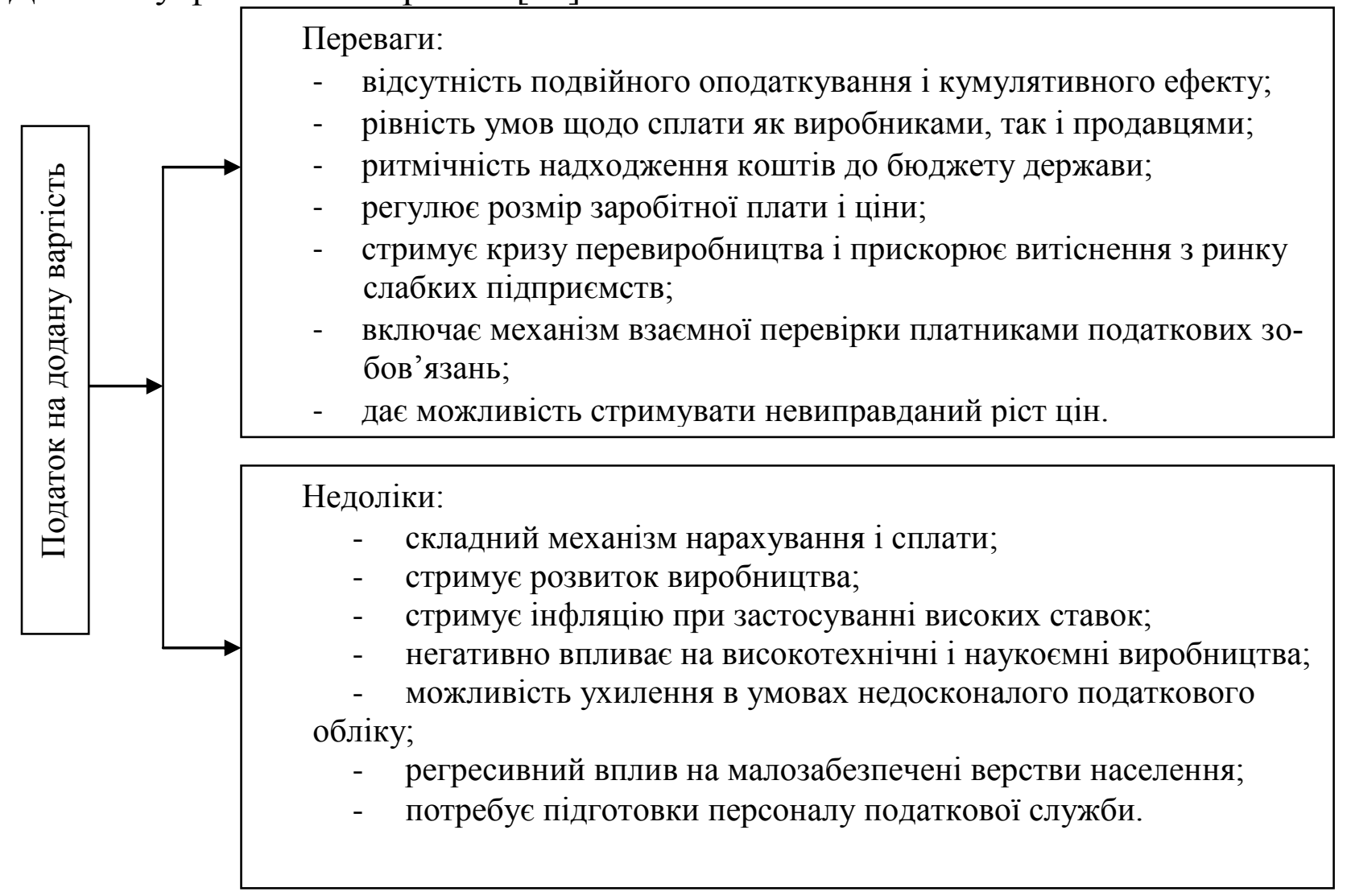

Рис. 1 Переваги і недоліки податку на додану вартість

Джерело : побудовано автором на основі опрацювання [17]

Принцип обчислення ПДВ полягає у механізмі співвідношення сум податкового зобов 'язання та сум податкового кредиту. Сума ПДВ, яку платник сплачує до бюджету, обчислюється як різниця між сумою податкового кредиту та сумою податкового зобов'язання. В разі якщо податковий кредит у звітному податковому періоді перевищує податкове зобов'язання, платник має право на перенесення від'ємного значення до складу наступного звітного податкового періоду [22]. Порядок заповнення і подання податкової звітності з ПДВ регламентується Наказом №21 від 28.01.2016 року «Про затвердження форм та Порядку заповнення і подання податкової звітності з податку на додану вартість» [23].
На момент настання «першої події» на дату виникнення податкових зобов'язань платник податку зобов'язаний скласти податкову накладну в електронній формі з дотриманням умови щодо реєстрації в порядку, визначеному законодавством, електронного підпису уповноваженої платником особи та зареєструвати іiі в Єдиному реєстрі податкових накладних. Реєстрація ПН/РК у Єдиному реєстрі повинна здійснюватися 3 урахуванням граничних строків визначених Податковим кодексом, зокрема для таких, що складені:

1) 31 по 15 календарний день (включно) календарного місяця - до останнього дня (включно) календарного місяця, в якому вони складені; 
2) 316 по останній календарний день (включно) календарного місяця до 15 календарного дня (включно) календарного місяця, наступного за місяцем, в якому вони складені.

Платник податку відповідно має право зареєструвати ПН/РК в Єдиному реєстрі податкових накладних згідно наступного алгоритму [24]:

1) Настання «першої події» (виникнення податкового зобов'язання).

2) Подання запиту (J1302001) в електронному кабінеті платника податків щодо наявного ліміту для реєстрації ПН/РК.

3) Отримання запиту (J1302001) в електронному кабінеті платника податків щодо наявного ліміту для реєстрації ПН/РК

4) Реєстрація податкової накладної/розрахунку коригування:

- якщо обчисленої суми вистачає, то реєстрація в СРПН;

- якщо обчисленої суми не виста-

чає, то або поповнення електронного рахунку ПДВ, або вхідний кредит.

Отже, податкове зобов'язання 3 ПДВ виникає при настанні першої 3 подій, або відвантаження товару, або отримання коштів від покупця. Після визначення суми, на яку платник ПДВ має право зареєструвати податкові накладні, відбувається співставлення 3 «лімітом реєстрації» і внесення податкової накладної до Єдиного реєстру податкових накладних. У випадку, коли сума податкової накладної перевищує ліміт реєстрації, реєстрація в Єдиному реєстрі не відбувається [16, c. 691].

Недостатня кількість коштів на рахунку платника зобов'язує його у визначені Кодексом строки перерахувати на електронний рахунок кошти
3 власного поточного рахунку в сумі недостачі. Таким чином, час реєстрації податкової накладної може тривати 15 діб, i, навіть, більше. Але перевищення встановленого строку реєстрації податкових накладних призводить до застосування штрафних санкцій, що зростають пропорційно до строку реєстрації. На практиці, від'ємне значення формули зустрічається на підприємствах, що містять в структурі собівартості своєї продукції, робіт і послуг, невелику частку витрат, пов'язану із залученням ресурсів з боку інших підприємств. Тобто, чим менше закуповується товарів, робіт і послуг у підприємств, які можуть видати податкову накладну, тим більша ймовірність не отримати позитивного значення суми, дозволенної для реєстрації. Зрозуміло, що не всі з цих підприємств працюють в тіні, але всі мають таку проблему. Якщо $\epsilon$ ймовірність отримати вхідну податкову накладну, бухгалтерія підприємства очікує їі, при цьому витрачається робочий час на подання запитів в Державну податкову службу. Іноді вона змушена спілкуватися 3 контрагентами і просити їх швидше зареєструвати і відправити свою податкову накладну. Зрозуміло, що такі дії жодним чином не спрощують процес справляння податку [25, с. 136].

Загалом, податок на додану вартість $\epsilon$ найбільш складним в адмініструванні. 3 метою підвищення рівня податкової дисципліни активно запроваджуються штрафні санкції за нереєстрацію/несвоєчасну реєстрацію ПН/РК (табл. 2), останні зміни до яких було внесено Законом України від 16.01.2020 року № 466-IX «Про внесення змін до Податкового кодексу України щодо вдосконалення 
адміністрування податків, усунення технічних та логічних неузгодженостей

у податковому законодавстві», який вступив в дію 23 травня 2020 р. [26].

Таблиця 2.

Штрафи за несвоєчасну реєстрацію (нереєстрацію) ПН/РК

\begin{tabular}{|c|c|c|c|c|}
\hline \multirow{2}{*}{$\begin{array}{l}\text { Характер } \\
\text { ПН/РК }\end{array}$} & \multicolumn{2}{|c|}{ До набуття чинності ЗУ № 466} & \multicolumn{2}{|c|}{ Після набуття чинності ЗУ № 466} \\
\hline & $\begin{array}{l}\text { Несвоєчасна } \\
\text { реєстрація }\end{array}$ & Нереєстрація & $\begin{array}{l}\text { Несвоєчасна } \\
\text { реєстрація }\end{array}$ & Нереєстрація \\
\hline $\begin{array}{l}\text { ПН/РК на } \\
\text { звільнені опе- } \\
\text { рації }\end{array}$ & - & - & \multirow{4}{*}{$\begin{array}{c}2 \% \text { від обсягу } \\
\text { постачання без } \\
\text { ПДВ, але не біль- } \\
\text { ше } 1020 \text { грн }\end{array}$} & \multirow{4}{*}{$\begin{array}{c}5 \text { \% від обсягу } \\
\text { постачання без } \\
\text { ПДВ, але не біль- } \\
\text { ше } 3400 \text { грн }\end{array}$} \\
\hline $\begin{array}{l}\text { ПН/РК на } \\
\text { нульові опе- } \\
\text { рації }\end{array}$ & - & - & & \\
\hline $\begin{array}{l}\text { ПН/РК } \\
\text { згідно з п. } 198.5 \\
\text { і ст. } 199 \text { ПКУ }\end{array}$ & \multirow{2}{*}{$\begin{array}{r}10-50 \% \\
\text { від суми ПДВ }\end{array}$} & \multirow{2}{*}{$\begin{array}{r}50 \%+50 \% \\
\text { від суми ПДВ }\end{array}$} & & \\
\hline $\begin{array}{l}\text { ПН на мін- } \\
\text { базу (тільки } \\
\text { ПН, не РК) }\end{array}$ & & & & \\
\hline
\end{tabular}

Джерело : складено автором на підставі опрацювання [26, 27]

До внесення змін до ПКУ було передбачено застосування штрафу в разі порушення граничних строків реєстрації, визначених п. 201.10.

Сума розрахованих штрафних санкцій залежала від тривалості (днів) порушення граничного терміну реєстрації ПН і РК та суми податкових зобов'язань, визначених у ПН і РК, і розраховувалась шляхом процентного співвідношення до суми податкових зобов'язань $з$ ПДВ. За новими правилами, із внесенням змін до ПКУ, передбачено застосування штрафних санкцій за порушення граничного терміну реєстрації ПН і РК, які визначено П. 201.10 ПКУ. Застосовуються штрафні санкції у розмірі $2 \%$ від обсягу постачання (без урахування ПДВ), але не більше ніж 1020 грн. До внесення змін до ПКУ було передбачено, що за порушення, яке виявлено під час податкової перевірки, застосовуються штрафні санкції, передбачені п. 1201.2 ПКУ, за відсутність реєстрації ПН і РК протягом визначеного терміну. За новими правилами, із внесенням змін до ПКУ, передбачено застосування штрафних санкцій у розмірі $5 \%$ від обсягу постачання (без урахування ПДВ), але не більше ніж 3400 грн [27]. Питання сплати ПДВ може виникати щодня, а не лише в кінці місяця або у момент складання декларації ПДВ. Спочатку на електронних рахунках залишатимуться суми ПДВ, які, не пропадуть, але будуть тимчасово вилучені з обігу. В зв'язку з цим деякі продажі можливо доведеться відкласти на декілька днів, переглянути договори $з$ відстроченням платежу з тим, щоб вистачило грошей на можливе поповнення електронних ПДВрахунків. Яким $\epsilon$ вирішення проблеми для спрощення сплати ПДВ платником та ефективним адмініструванням органами державної податкової служби? На нашу думку, одним з ключових завдань $\epsilon$ зміна моменту виникнення податкових зобов'язань 3 податку на 
додану вартість, має бути лише одна подія - відвантаження товарів (передача робіт, послуг).

Висновки. Отже, вважаємо, що в реаліях України подальшого вивчення та імплементації потребує диференційоване оподаткування та введення пільгової ставки податку для окремих груп товарів, гармонізація нормативно-правових положень та елементів механізму адміністрування податку на додану вартість 3 принципами системи оподаткування ЄС. Водночас, подальшому підвищенню ефективності електронного адміністрування ПДВ безумовно буде сприяти не тільки вирішення принципових положень оподаткування, але також створення технічних умов i впорядкування його функцій, що передбачає розширення можливостей електронного кабінету платника податків, забезпечення швидкості, надійності і захищеності електронного документообігу, організаційних та інформаційних процесів. Системне і комплексне впровадження сучасних технологій адміністрування податків дозволить підвищити податкову прозорість, рівень дотримання податкових норм, результативність протидії розмиванням податкової бази та ухиленням від оподаткування.

\section{Список використаної літератури}

1. Дадашев А. 3., Лобанов А. В. Налоговое администрирование в Российской Федерации. М., 2002. С. 4-5.

2. Шалімова Н.С., Магопець О.А. Сутність та загальні принципи адміністрування податків. URL : http://dspace.kntu.kr.ua/jspui/bitstream/ 123456789/2400/1/66.pdf (дата звернення : 05.09.2020).

3. Чиж В.I. Податкове адміністрування як спосіб забезпечення економічної безпеки регіону. Економіка та право, 2016. № 2 (44). С.47-52.

4. Федосов В., Опарін В., Льовочкін С. Фінансова реструктуризація в Україні: проблеми і напрямки: монографія. К.: КНЕУ, 2002. 415 с.

5. Крисоватий А.І. Теоретико-організаційні домінанти та практика реалізації податкової політики в Україні: монографія. Тернопіль: Карт-бланш, 2005. 320 с.

6. Бечко П.К., Лиса Н.В. Податковий менеджмент: навч. посіб. К.: Центр учбової літератури, 2009. 288 с.

7. Перонко И. А., Красницкий В. А. Налоговое администрирование. Налоговый вестник, 2000. № 10. С. 22.

8. Андрущенко В.Л. Фіскальне адміністрування як наука i мистецтво. Фінанси України, 2003. № 6. С. 27-35.

9. Мельник В.М. Проблеми теорії та практики адміністрування податків в Україні. Актуальні проблеми економіки, 2003. № 5. С. 40-43. 
10. Нікітшин А.О. Адміністрування податків в умовах фінансово-економічної кризи. Фінанси України, 2010. № 1. С. 38-45.

11. Воронов А. М. Налоговое администрирование: административно-правовой аспект. Вопросы экономики и право, 2012. № 10.

12. Подолянчук О.А. Податок на додану вартість: сутність та стан первинного обліку. URL : http://repository.vsau.org/getfile.php/13017.pdf (дата звернення : 05.09.2020).

13. Бондаря М.I. , Лисенко Н.М. Облік і звітність підприємств у системі оподаткування: навч. посіб. К.: ДННУ «акад. фін. управління», 2014. 585 с.

14. Економічна енциклопедія : у 3-х томах. / ред. С. В. Мочерний. К. : «Академія», $2001.847 \mathrm{c.}$

15. Оксенюк О.I. Фіскальна ефективність податку на додану вартість векономіці України: дис. к.е.н.: 08.00.08 /О.І. Оксенюк. Львів, 2015. 231 с.

16. Дугар Т.Є. Проблема адміністрування податку на додану вартість на сучасному етапі. Економіка і суспільство, 2016. Вип. №2. С. 689-693.

17. Ходикіна А.А., Бурковська А.В. Актуальні тенденції обліку розрахунків 3 податку на додану вартість. Глобальні та національні проблеми економіки, 2015. Вип. 8. С. 1196-1199.

18. Податковий кодекс України від 02.12.2010 р. № 2755-VI (із змінами та доповненнями). URL : http: //zakon4.rada.gov.ua/laws/show/2755- 17. (дата звернення : 05.09.2020).

19. Закон України від 31 липня 2014 року № 1621-VII "Про внесення змін до Податкового кодексу України та деяких інших законодавчих актів України" 20. Закон України від 7 жовтня 2014 року № 1690-VII "Про внесення змін до Податкового кодексу України щодо вдосконалення оподаткування інвестиційної діяльності"

21. Лист Державної фіскальної служби України від 26.01.2016 р. № 1389/6/9999-19-03-02-15 «Про розгляд звернення». URL : http: //sfs.gov.ua /baneryi /podatkovi- konsultatsii /konsultatsii-dlyayuridichnih-osib/66280.html (дата звернення : 05.09.2020).

22. Порядок ведення Єдиного реєстру податкових накладних, затверджений постановою Кабінету Міністрів України від 29.12.2010 р. № 1246 (із змінами та доповненнями). URL : http: //zakon3.rada.gov.ua/laws /show/1246-2010-п (дата звернення : 05.09.2020). 
23. Лист Державної фіскальної служби України від 02.02.2016 р. № 3240/7/9999-19-03-00-17 «Про податкову декларацію з податку на додану вартість 31 січня 2016 року». URL : http://sfs.gov.ua/zakonodavstvo/ podatkovezakonodavstvo/listi-dps/6246.html (дата звернення : 5.09.2020).

24. Лист ДПС України від 23.01.2020 № 1174/7/99-00-07-03-02-07 «Зміни, внесені Законом № 344 до пункту 8 підрозділу 2 розділу ХХ ПКУ»

25. Артюх О. В., Топольницька Н. Д. Фінансовий контроль податку на додану вартість: питання оптимізації. Науковий вісник Ужгородського національного університету, 2016. № 8. С. 136.

26. Закон України від 16 січня 2020 року №466 «Про внесення змін до Податкового кодексу України щодо вдосконалення адміністрування податків, усунення технічних та логічних неузгодженостей у податковому законодавстві.» URL : https://zakon.rada.gov.ua/go/466-20 (дата звернення : 05.09.2020).

27. Постанова Кабінету Міністрів України «Деякі питання електронного адміністрування податку на додану вартість» № 569 від 16.10 .2019 р. (із змінами та доповненнями) URL : http://zakon3.rada.gov.ua/laws/show/569-2014-п (дата звернення : 05.09.2020).

28. 4 головні проблеми відшкодування ПДВ в Україні. URL: https://gmk.center/ua/opinion/4-golovni-problemi-vidshkoduvannya-pdv-v-ukraini/ (дата звернення : 05.09.2020).

29. ДПС: проблем із надходженням платежів до бюджету у 2020 році немає. URL : http://www.visnuk.com.ua/uk/news/100018838-dps-problem-iz-nadkhodzhe nnyam- platezhiv-do-byudzhetu-u-2020-rotsi-nemaye (дата звернення : 05.09.2020). 